\title{
Hemorrhagic Epidermoid Cyst in Cerebellar Vermis
}

\section{Serebellar Vermis Yerleşimli Hemorajik Epidermoid Kist}

\author{
Chuan-Yuan $\mathrm{TAO}^{1}$, Pan $\mathrm{WEI}^{2}$, Jia-Jing WANG ${ }^{3}$, Chao YOU ${ }^{1}$ \\ ${ }^{1}$ West China Hospital, Sichuan University, Department of Neurosurgery, Chengdu, Sichuan, China \\ ${ }^{2}$ The 452nd Hospital of PLA, Department of Neurosurgery, Chengdu, Sichuan, China \\ ${ }^{3}$ West China Hospital, Sichuan University, Department of Neurosurgical ICU, Chengdu, Sichuan, China
}

Corresponding Author: Chao YOU / E-mail: tcy106@163.com

\begin{abstract}
Intracranial epidermoid cysts are usually located in the paramedian regions with characteristic imaging features. Intracystic hemorrhage is rarely reported with most in the cerebellopontine angle area. We described a case of hemorrhagic epidermoid cyst in cerebellar vermis. The patient was a 21-year-old male presenting with a first episode of convulsive seizure attack as the initial and sole symptom. Head computed tomography showed a mass lesion in the cerebellar vermis with high density and nodular low density in the back of the lesion. Magnetic resonance imaging revealed most of the lesion was hypointense to isointense, extremely hypointensity on T1-, T2-weighted imaging respectively. The nodule was hyperintense on both T1- and T2-weighted images. The atypical clinical presentation, location and radiological features of intracranial epidermoid cyst make accurate diagnosis quite challenging. In such cases, scrutinized histopathological examination is necessary to exclude the malignancy that may need radio/chemotherapy.
\end{abstract}

KEYWORDS: Cerebellar tumor, Cerebellopontine angle, Epidermoid cyst, Hemorrhage

\section{öz}

İntrakraniyal epidermoid kistler genellikle paramedian bölgelere yerleşirler ve karakteristik görüntüleme özellikleri vardır. İntrakistik hemoraji nadiren rapor edilmiştir ve bunların çoğunluğu serebellopontin açı yerleşimlidir. Serebellar vermis yerleşimli bir hemorajik epidermoid kist olgusunu sunuyoruz. Olgu, ilk ve tek semptomu konvülzif epileptik atak olan 21 yaşında erkek hastadır. Kraniyal bilgisayarlı beyin tomografisi serebellar vermisde yüksek dansiteli kitle lezyonunu gösterirken, lezyonun arka kısımları ise nodüler tarzda ve düşük dansiteli idi. Manyetik rezonans görüntüleme ise T1 ağırlıkı kesitlerde hipointensden izointense doğru uzanan bir lezyonu gösterdi. T2 ağılıklı kesitlerde ise belirgin şekilde hipointensite mevcuttu. Nodül ise T1 ve T2 kesitlerde hiperintens idi. Atipik klinik başlangıç, yerleşim ve radyolojik özellikleri intrakraniyal epidermoid kistlerin kesin tanısını zorlaştırmaktadır. Sunduğumuz olguda dikkatli bir histopatolojik inceleme radyo/kemoterapi gerektiren malign tümörleri ekarte etmek açısından oldukça önemli idi.

ANAHTAR SÖZCÜKLER: Serebellar tümör, Serebellopontin açı, Epidermoid kist, Hemoraji

\section{INTRODUCTION}

Intracranial epidermoid cyst represents approximately 0.2 to $1 \%$ of all intracranial tumors (3).They usually occur laterally. The most common location in the posterior fossa is the cerebellopontine angle (CPA) area. The fourth ventricle and cerebellar hemisphere location are also occasionally reported. However, occurrence in the cerebellar vermis is exceptionally rare $(3,4)$. We present a vermian epidermoid tumor with intracystic hemorrhage. The initial symptom was seizure and the radiologic imaging was unusual. We discussed the possible reasons for the atypical manifestations and emphasized the importance of histological examination.

\section{CASE REPORT}

A 21-year-old male soldier experienced a first episode of convulsive seizure attack when singing. On admission, he was alert without significant headache or cerebellar signs. Computed tomography (CT) of the brain disclosed a hyperdense mass lesion in the cerebellar vermis and obstructive hydrocephalus. A small portion within the lesion was found low in density (Figure 1A). Most of the lesion on magnetic resonance imaging (MRI) was hypointense to isointense on T1-weighted images and extremely hypointense on T2-weighted images (Figures 1B, C). Enhancement was not noticed (Figure 1D). The nodule in the back of this lesion was heterogeneously hyperintense on both $\mathrm{T} 1$ and $\mathrm{T} 2$ weighted images, also absent of contrast enhancement.

He underwent midline suboccipital craniotomy. After opening the dura, an extra-axial mass with a transparent capsule was seen. We identified mud-like chronic hematoma in brown color and yellow lipid debris when the capsule was cut open (Figure 2A). During surgery, the lesion was totally removed; no hair or obvious calcification or ossification was observed.

Postoperative course was uneventful. Histological examination showed keratin, stratified squamous epithelium and blood. Exhaustive looking for skin adnexal structures or tissue derived from mesoderm or endoderm as well as malignant elements failed. Epidermoid cyst accompanying hemorrhage was confirmed (Figure 2B). The patient recovered well with no morbidity. At 1-year follow up, MRI of brain revealed disappearance of hydrocephalus and the lesion. 


\section{DISCUSSION}

Intracranial epidermoid cyst is a congenital lesion with a slow, long clinical course and an average age at diagnosis around 40 years (1). The CPA region is the most common location followed by the forth ventricle in the posterior fossa, where trigeminal neuralgia, hearing loss and gate ataxia are the main symptoms (1). The lesion in cerebellar vermis is extremely rare $(1,2)$. In our case, chronic hemorrhage may be responsible for the relatively young age at the disease

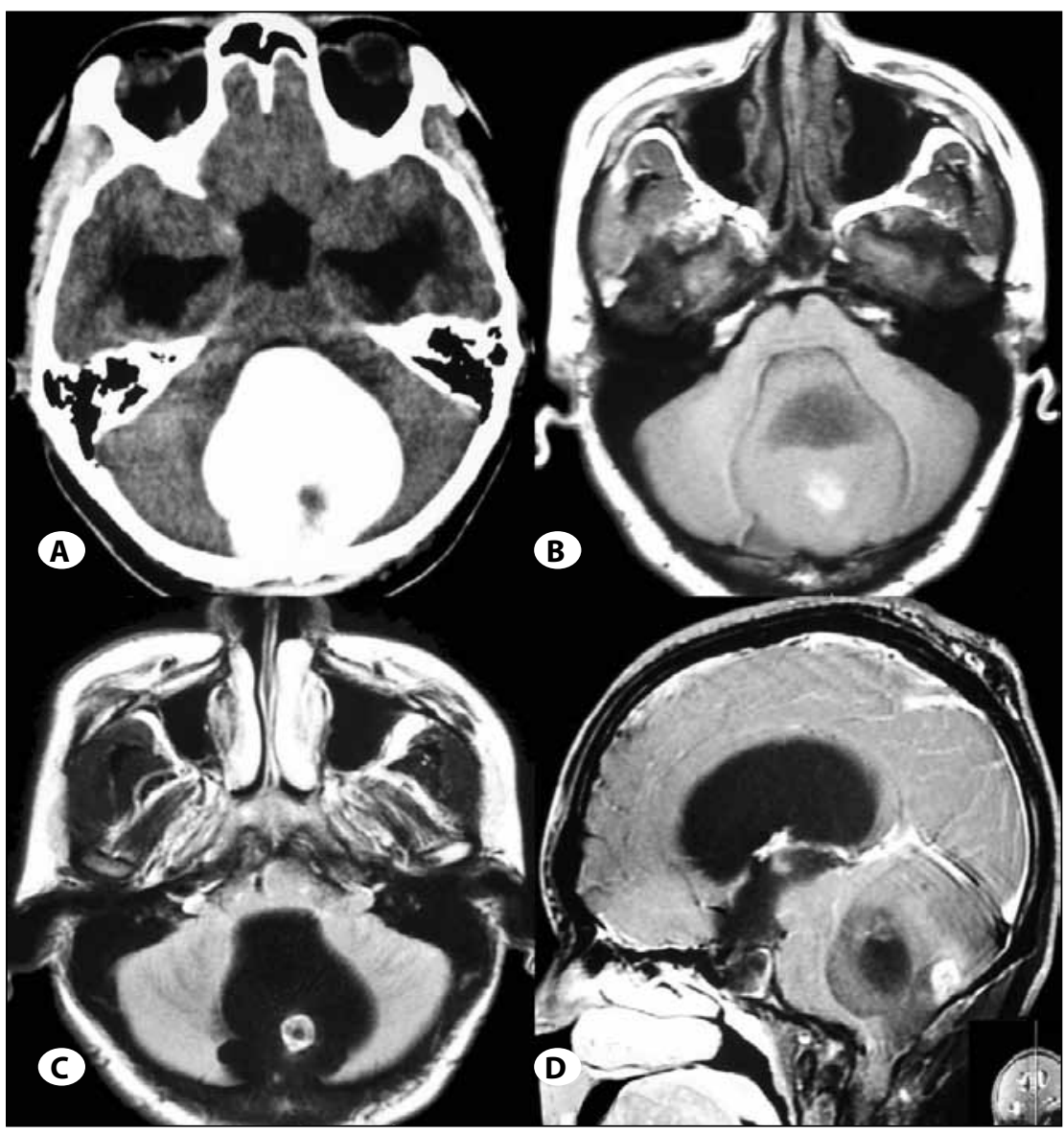

Figure 1: A) Head CT showed a mass lesion in the cerebellar vermis with high density and nodular low density in the back of the lesion. B) On axial T1-weighted MRI, the $53 \times 55 \times 48 \mathrm{~mm}$ lesion was hypointense to isointense and the nodule was hyperintense. C) Axial T2-weighted MRI shows extremely hypointensity of the lesion and the nodule is heterogeneously hyperintense.

D) No enhancement is observed on sagittal contrast T1-weighted MRI.

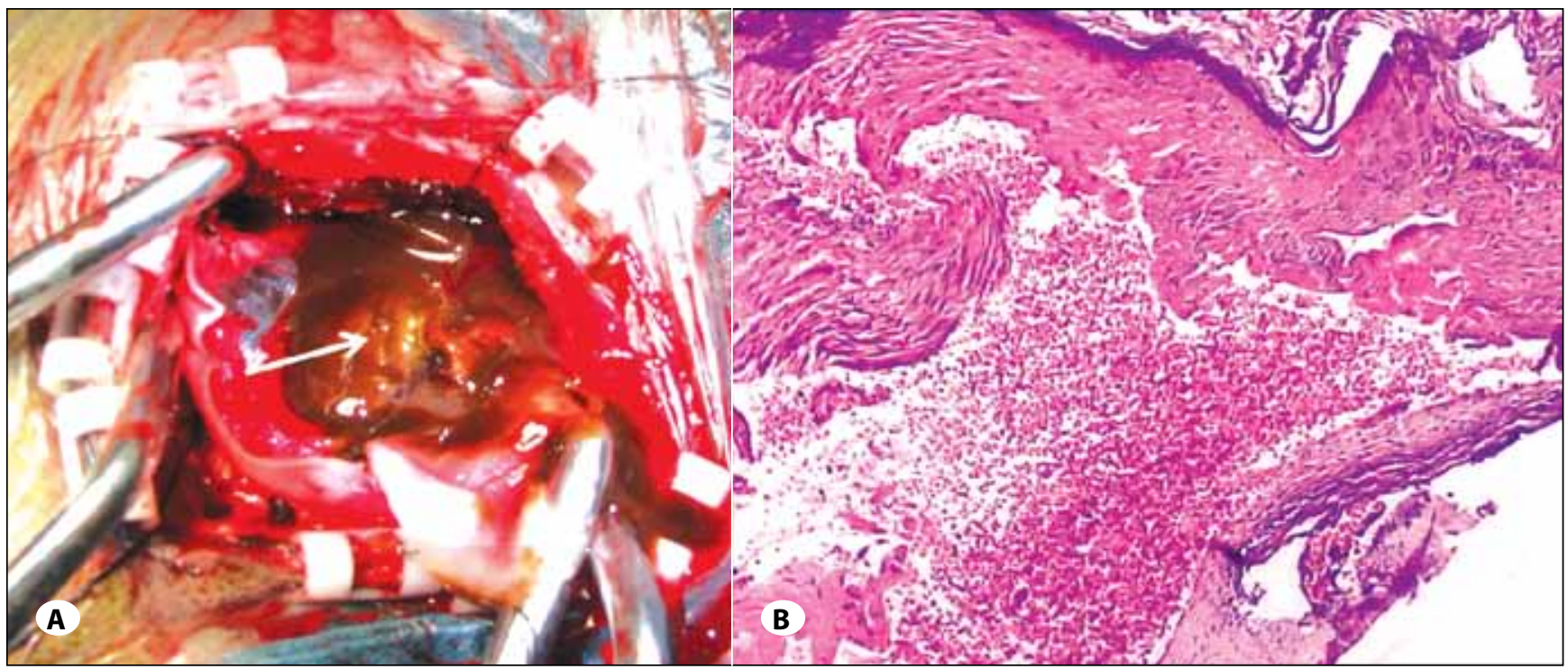

Figure 2: A) Photograph during operation revealed mud-like old hemorrhage and yellow lipid debris (arrow). B) Histological examination showed keratin, stratified squamous epithelium and blood, consistent with hemorrhagic epidermoid cyst $(\mathrm{HE}, \times 200)$. 
onset due to accelerated growth of the lesion. In addition, seizure attack became the single presentation, probably induced by singing which contributed to the acute elevation of intracranial pressure in the setting of hydrocephalus. It was different from the report by Singh et al. in which the patient presented seizure in sleep because of acute hemorrhage of epidermoid cyst in the supratentorial compartment (5).

The radiological manifestation of our case was quite atypical. It has been reported that intratumoral hemorrhage is the most common cause of changes in the signal intensity (1, 4). Meanwhile, the signal intensity on MR imaging varies depending on the contents. Hyperintensity on both T1and T2-weighted images can be due to a semi-liquid cystic content with high protein concentration; high signal intensity on T1-weighted and low signal intensity on T2-weighted images can be caused by even thicker toffee-like content with a combination of high protein content and high viscosity; low signal intensity on T1- and T2-weighted images can be attributed to an unusual composition of epithelial debris, crystals of cholesterol, and keratin (1). In our case, the signal intensity of most of the lesion partly accords with that of chronic hematoma while the signal feature of the nodule may be related to the intracystic content of high protein.

When epidermoid cyst occurs in the cerebellar vermis with hemorrhage, preoperative misdiagnosis is quite frequent $(1,4)$. Surgeons should recognize its uncommon features to avoid surgical complications such as chemical meningitis. Additionally, careful histological examination is essential to differentiate from other diseases such as immature teratoma and to detect malignant transformation which requires adjuvant therapy after surgery (2).

\section{CONCLUSION}

Vermian epidermoid cyst is very rare and can have seizure as the sole clinical presentation. When complicating with hemorrhage, the differentiation from other entities is difficult by preoperative imaging features. Scrutinized histopathological examination is necessary to exclude the malignancy which may need radio/chemotherapy.

\section{REFERENCES}

1. Chen CY, Wong JS, Hsieh SC, Chu JS, Chan WP: Intracranial epidermoid cyst with hemorrhage: MR imaging findings. AJNR Am J Neuroradiol 27:427-429,2006

2. Michael LM 2nd, Moss T, Madhu T, Coakham HB: Malignant transformation of posterior fossa epidermoid cyst. $\mathrm{Br} \mathrm{J}$ Neurosurg 19:505-510,2005

3. Raghunath $\mathrm{A}$, Devi $\mathrm{BI}$, Bhat $\mathrm{DI}$, Somanna S: Unusual complications of a benign tumor- our experience with midline posterior fossa epidermoids. Br J Neurosurg 27:69-73, 2013

4. Ren X, Lin S, Wang Z, Luo L, Jiang Z, Sui D, et al: Clinical, radiological, and pathological features of 24 atypical intracranial epidermoid cysts. J Neurosurg 116:611-621, 2012

5. Singh N, Symons SP, Montanera W, Kaderali Z, Muller PJ, Munoz DG, Marotta TR: Hemorrhagic epidermoid cyst in a patient with generalized tonic clonic seizure. J Clin Neurosci 20:750-752, 2013 